\title{
DIE RADIO IN AFRIKA
}

\section{Inleiding:}

Omvang van radio-uitsendings in en na Afrika. - Redes vir die versnelde tempo van uitbreiding. - Radio as die geskikste massa-kommunikasiemiddel vir Afrika. - Faktore wat die verspreiding bemoeilik. - Skouspelagtige toename in luistertalle.

Toe Plinius, wat in die jaar 79 oorlede is, in sy „Historia Naturalis" verklaar het dat daar altyd iets nuuts uit Afrika afkomstig is, kon hy nouliks voorsien het dat die ,iets" negentien eeue later in die lug sou setel wat hierdie reuse-vasteland oorspan - 'n Babelse spraakverwarring en 'n ongekende, verbete woorde-oorlog in die etergolwe, onder meer daarop bereken om die harte en hoofde van derduisendes te verower.

Aan die begin van 1966 het Afrika se meer as vierhonderd uitsaaistasies in 186 tale, insluitende velerlei inheemse tale, aan die bewoners van hierdie vasteland uitgesaai. Van buite Afrika af het sewe-en-dertig lande reeds in hierdie stadium uitsendings in vier-en-twintig tale $1436 \frac{1}{2}$ uur lank per week op Afrika gerig.

Daar kan geen twyfel bestaan dat van alle ontwikkelingsprojekte wat in die jongste jare in Afrika en ten behoewe van Afrika onderneem is, die uitbreiding van radio-kommunikasies die mees skouspelagtige was nie. Sommige van die mees onderontwikkelde lande spog met radiotoerusting weliswaar in die meeste gevalle nog nie afbetaal nie - wat wêreldmoondhede na die kroon steek, terwyl een-derde van die totale buitelandse sendkrag van die wêreld reeds op Afrika gerig is.

En die uitbreiding en uitbouing begin nou eers in der waarheid in snelrat kom. Die S.A.U.K. stuur byvoorbeeld op 1 Mei sy omvattende Buitelandse Diens van stapel wanneer hy twee van sy vier kragtige kortgolfsenders van $250 \mathrm{kw}$. elk inspan om daaglikse uitsendings in vyf tale na Afrika uit te dra. Dit is slegs die eerste fase van wat beplan is om eerlang Suid-Afrika se wêreldwye kortgolfdiens in nege tale te wees. Oral op die vasteland en ook daarbuite word met koorsagtige haas gewerk om die radionet dubbel en dwars oor die $11,635,000$ 
vierkante myl van Afrika te span.

Om in hier'die stadium met nog enkele voorbeelde te volstaan van bedrywighede wat of pas afgehandel is of reeds onderneem word: Swaziland se nuwe radiostasie op Mbabane het op 18 April met uitsendings begin oor 'n sender van 10 kw.; Britse ingenieurs het vandeesmaand in Maseru aangekom om behulpsaam te wees met die daarstelling van Radio Lesotho; Tanzanië se Minister van Inligting het gedurende die laaste week van Desember verlede jaar die hoeksteen gelê van 'n nuwe kortgolfstasie met 'n sender van $100 \mathrm{kw}$. wat teen 'n koste van $R 2,800,000$ deur Rooi-Sjinese tegnici net buite Dar-es-Salaam opgerig word; Russiese tegnici is behulpsaam met die oprigting van 'n kragtige sender buite Nairobi om aan Die Stem van Kenia, wat reeds op 2 Julie 1964 deur premier Jomo Kenyatta as sodanig geopen is, groter trefkrag te verleen; Francistown se veelbesproke „bossender" verhef nou reeds vier maande lank sy stem in die rigting van Rhodesië; Ghana se moderne ateljee-sentrum by Accra en uitgebreide nuwe sendernet by Ejura - die sendernet sluit twee kortgolfsenders van $250 \mathrm{kw}$. elk in - is in die loop van verlede jaar in gebruik geneem; Brittanje se heruitsendingstasie wat teen ' $n$ koste van $\mathrm{R} 4$ miljoen op Ascensioneiland opgerig word en oor vier kortgolfsenders van $250 \mathrm{kw}$. elk sal beskik, is reeds ver gevorder op die weg na voltooiing; Wes-Duitsland het ' $n$ heruitsendingstasie in Rwanda in gebruik geneem en kommunistiese lande hulle radio-uitsendings na Afrika op onrusbarende wyse uitgebrei - ten spyte daarvan dat Rusland, Kommunistiese Sjina en die Oos-Europese satellietstate gesamentlik hulle Afrika-uitsendings in die jare 1958 tot 1963 honderdvoudig vermeerder het, het hierdie uitsendings naamlik verder toegeneem tot ' $n$ huidige totaal van 336 uur per week waarvan Rusland vir $133 \frac{1}{2}$ uur sorg en Peking, in Kommunistiese Sjina, vir 56 uur.

Daar bestaan heelwat voor die handliggende redes vir die rustelose radio-bedrywigheid in en vanweë Afrika. In bepaalde gevalle word klaarblyklik eerlik daarna gestrewe om sonder sinistêre bybedoeling deur middel van die radio soveel inlig. ting, voorligting, vermaaklikheid en opvoeding moontlik aan soveel moontlik van die 258 miljoen inwoners van die kontinent oor te dra. Prysenswaardige pogings om met behulp van opvoedkundige uitsendings ongeletterdheid te bestry - in 
1963 was slegs $20 \%$ van die totale bevolking van Afrika ongeletterd - verdien byvoorbeeld in hierdie verband vermelding. Ook is dit duidelik dat ' $n$ eie radio met 'n aansienlike trefwydte, verkieslik tot buite die landsgrense, as 'n onontbeerlike statussimbool deur alle opkomende Afrikastate beskou word. Terselfdertyd ly dit geen twyfel nie dat hierdie magtige kommunikasiemiddel op gewetelose wyse deur veral die Kommunistiese lande en die merendeel Afrikastate as politieke instrument aangegryp word in die ideologiese stryd om besit van die massas van Afrika. Op die aard en inhoud van die propaganda-oorlog wat in ons lugruim tier, kom ons later terug.

Maar waarom juis by voorkeur van die radio gebruik maak om die miljoene van Afrika te bereik? Soos tereg deur Harald Voss in sy werk ",Rundfunk und Fernsehen in Afrika" beklemtoon word, speel die radio as massakommunikasiemiddel in Afrika 'n aansienlik gewigtiger rol as in Europa. Aangesien in byna alle Afrikalande die grootste deel van die bevolking nog nie kan lees en skryf nie, is die bereik van die radio wesenlik groter as dié van die pers. Wat die gesteldheid van 'n land se verbindingsmiddels ook al mag wees, kan die radio alle gebiede bedien, terwyl die nog gebrekkige uitbouing van die verkeersnet in die pad van die verspreiding van die film en die pers staan. Daardeur word die radio een van die deurslaggewende instrumente vir die verbinding van Afrikalande onderling asook die verbinding van Afrikalande met die res van die wêreld. Dit is interessant om daarop te let dat daar in 1963 slegs ongeveer 2,300 bioskope in Afrika was, terwyl die vasteland se 231 dagblaaie in 1961 'n totale sirkulasie van slegs drie miljoen vir die hele Afrika gehad het.

Tegelykertyd bemoeilik egter ' $n$ antal faktore die verspreiding van die radio in Afrika. Die klimaat stel aan die materiaal die hoogste eise. Dit moet teen vogtigheid en stofinwerking byna soveel verseker wees as teen hitte en uiterste temperatuurwisselinge. Daarby kom die besonder intensiewe atmosferiese steurings van die tropegebied wat, net soos die nedersettingstruktuur van die meeste Afrikalande, 'n radioontwikkeling op Europese lees geskoei - dit wil sê deur baie sterk langgolfsenders en ' $n$ digte net van mediumgolfen kortgolfsenders - onmoontlik maak. Met die oog op die wydverspreide en yl bevolking van die Afrikagebiede sou so 'n stelsel beleggings vereis wat nie uit die beperkte middele 
van hierdie „ontwikkelingslande" finansier sou kon word nie. Die ruggraat van die radiodiens word dus in die meeste gebiede gevorm deur kortgolfsenders van gemiddelde sterkte wat weens die intensiewe sonvlek-invloed gedurende die dag dikwels 'n ander frekwensie gebruik as vroeg in die oggend en saans. Hierdie senders is vir die bediening van die besondere land bestem. Swakkere mediumgolf- en in enkele gevalle ook kortgolfsenders sorg daarby in baie stadsentrums vir 'n ontvangs van beter kwaliteit.

Nie dat alle Afrikalande hulle te veel aan finansiële onverınoë steur nie. In hulle gretigheid om ook oor eie buitelandse clienste te beskik, is in verskeie gevalle tegniese en finansiële hulp van veral kommunistiese lande aanvaar en sterk kortgolfsenders op hierdie wyse bekom.

Voss noem die ongewoon heterogene luistertal as nog 'n faktor wat radiowerk in Afrika bemoeilik. Vanselfsprekend skep hierdie besondere samestelling van luisteraars ook probleme vir lande wat van buite af uitsendings op Afrika rig. Met die uitsondering van ' $n$ paar Arabiese state in die noorde van die vasteland, besit geen Afrikaland 'n eenvormige taal nie. Selfs in klein lande word die radioprogramme gevolglik in 'n halfdosyn en meer tale uitgesaai. By die Nigeriese radio word - streek en plaaslike programme bygereken - van twee-entwintig tale gebruik gemaak. Sonder om die tale in berekening te bring wat in die spesiale uitsendings vir immigrante gebesig word, bedien die S.A.U.K. hom byvoorbeeld gereeld in sy binnelandse programme van dertien tale - Afrikaans en Engels asook vier Indiese en sewe Bantoetale. By die taalaspek kom nog die dikwels onvoorstelbare groot onderskeid tussen die stedelike, plattelandse, geletterde, ongeletterde, ontstamde en nog stamgebonde nie-blanke luisteraars.

Om andermaal en vir oulaas by finansies stil te staan as ' $n$ wesenlike probleem in verband met radiobedrywighede in Afrika. Die beskeie lewenstandaard en die geringe bevolkingsdigtheid in groot dele van Afrika het tot gevolg dat die radio nie slegs deur luisteraarsgelde gefinansier kan word nie. Slegs in die Republiek van Suid-Afrika en in 'n paar van die Noord-Afrikaanse lande het die radio noemenswaardige inkomste uit hierdie bron wat egter ook nog deur verdere inkomstebronne aangevul moet word. Die meeste radio-instansies verkry aansienlike ondersteuning uit die staatshuishou- 
ding. Daarbenewens is aan baie stasies die geleentheid gebied om deur middel van kommersiële radio bykomstige inkomste te verdien. In die Portugese gebiede en in Liberië word trouens die meeste radiostasies op hierdie wyse gefinansier.

Die vraag ontstaan of die kool in der waarheid die sous werd is en daar enigsins op groot skaal geluister word na die talle programme wat Afrikastasies en omroepe in die buitewêreld met groot moeite en teen ontsaglike finansiële uitgawe op die bevolking van Afrika loslaat. Is die geweldige geskarrel om radio-ontwikkeling ten opsigte van Afrika ten alle koste teen 'n nog vinniger tempo te laat plaasvind die moeite werd indien daar, gedagtig aan die lae koopkrag van sewentig persent van die bevolking, bitter min eienaars van radio-ontvangstoestelle sou wees?

'n Tiental jare gelede sou hierdie vraag met regverdiging gestel kon gewees het. In 1955 was daar byvoorbeeld ten suide van die Sahara - en met uitsluiting van Suid-Afrika - slegs 360,000 ontvangstoestelle. Danksy onder andere die koms van die transistorradio en die goedkoper ontvangers wat veral onder die druk van Japanse mededinging op die mark geplaas is, dui amptelike statistiek daarop dat die getal luisteraars in Afrika sedertdien teen 'n geweldige tempo gestyg het. Teen 1962 het die 360,000 ontvangstelle in die bepaalde gebied vermeerder tot 2,600,000 — 'n toename van 622 persent.

In sy reeks kaarte en statistieke oor Afrika wat met kulturele en opvoedkundige aspekte te make het, stel die AfrikaInstituut in uitgawe nr. 3 van Januarie 1963 die aantal radioontvangtoestelle vir die hele Afrika op sowat 5,000,000. Drie jaar later wys die "1966 World Radio TV Handbook" op meer as ' $n$ verdubbeling van hierdie getal en dui hy die totale aantal ontvangstelle vir die hele Afrika op die huidige oomblik as bykans elfmiljoen aan, naamlik 10,927,351.

Dit is interessant om daarop te let dat die mees noordelike en die mees suidelike lande oor die meeste ontvangstelle beskik. Volgens die „World Radio TV Handbook” het die Verenigde Arabiese Republiek (bevolking 30-miljoen) tans 3,500,000 ontvangstelle en Suid-Afrika (bevolking 16-miljoen 750,000) $2,600,000$ ontvangers.

Enkele ander belangwekkende syfers is die volgende: $\mathrm{Ma}$ rokko (bevolking 12⿺-miljoen) 700,000 ontvangstelle; Soedan (bevolking 12-miljoen 150,000) 600,000 ontvangstelle; Ghana 
(bevolking 7-miljoen) 505,000 ontvangstelle; Nigerië (bevol-

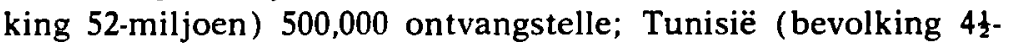
miljoen) 370,000 ontvangstelle; Kenia (bevolking 8-miljoen $900,000) 350,000$ ontvangstelle; Ethiopië (bevolking 21-miljoen) 300,000 ontvangstelle; Algerië (bevolking 10-miljoen 785,000) 250,000 ontvangstelle; Republiek van die Kongo (bevolking 14miljoen) 200,000 ontvangstelle; Oeganda (bevolking 6-miljoen 800,000 ) 200,000 ontvangstelle; Senegal (bevolging 3-miljoen 400,000 ) 150,000 ontvangstelle; Liberië (bevolking 2-miljoen $100,000) \quad 130,000$ ontvangstelle; Sierra Leone (bevolking 2tmiljoen) 120,000 ontvangstelle; Tanzanië (bevolking 10-mil-

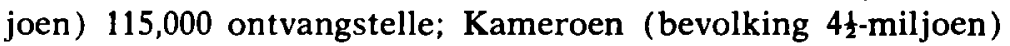
115,000 ontvangstelle; Mauritius (bevolking 750,000) 120,000 ontvangstelle; Rhodesië (bevolking 4-miljoen 136,800) 80,000 ontvangstelle; Zambië (bevolking 3-miljoen 650,000) 77,000 ontvangstelle, en Malawi (bevolking 4-miljoen 19,000) 75,000 ontvangstelle.

In die inleidende gedeelte van hierdie referaat het ons die aandag bepaal by die omvang wat radio-uitsendings in en na Afrika reeds aangeneem het; die geweldige tempo waarteen uitbreidings tans aangepak word; die klaarblyklike redes vir die versnelde tempo; radio as die geskikste massa-kommunikasiemiddel vir Afrika; faktore wat die verspreiding van die radio in Afrika bemoeilik, en die skouspelagtige toename in die aantal luisteraars.

Graag staan ons vervolgens afsonderlik stil by die ontwikkeling van die radio in Afrika, by radio-uitsendings na Afrika en by die aard en inhoud van die giftige propagandaoorlog wat in ons lugruim gevoer word en die gevaarlike afmetings wat dit aanneem. Ook wy ons kortliks aandag aan die uitsendings van die S.A.U.K., met spesiale verwysing na sy Bantoe- en Buitelandse Dienste vanweë hulle betrekking op die res van Afrika en op uitsendings uit Afrikalande.

\section{Die ontwikkeling van die radio in Afrika:}

Drie stadiums van ontwikkeling. - Eerste Afrikastate met groot senders. - Verandering in innerlike struktuur sedert Tweede Wêreldoorlog. - Hele vasteland prakties reeds ontgin. - Verskil in Britse, Franse en Portugese benadering. - Stigting van URTNA. 
Daar word gewoonlik drie stadiums as tiperend van die ontwikkeling van die radio in Afrika aangedui. Hulle word insiggewend deur Harald Voss in „Rundfunk und Fernsehen in Afrika" toegelig.

In die eerste stadium ontstaan, dikwels deur privaat inisiatief, klein senders wat slegs ' $n$ beperkte gebied meestal in die omgewing van die hoofstad en ander nedersettingsentrums versorg. Die tweede stadium word gekenmerk deur die strewe om die hele gebied vir die radio te ontgin. Indien die radio nie reeds in die eerste fase deur die Staat beheer word nie, word dit in die tweede deur hom oorgeneem of het hy minstens onregstreeks daarby belang. Die Portugese gebiede en Liberië vorm in hierdie opsig vandag nog 'n uitsondering deur geen verbintenis met die Staat te hê nie. In die derde fase oorskry die radio territoriale grense. Daar ontstaan groot senders wat benewens die nasionale nou ook 'n internasionale program uitsaai. Die opbou van so ' $n$ internasionale sendernet is so eng met die ontstaan van selfstandige Afrikastate verbonde dat dit in die merendeel gevalle byna as een van die simbole van die politieke onafhanklikheid aangewys kan word.

As eerste Afrikaland begin Egipte in 1952 met die opbou van groot senders. Daarná volg ander Noord-Afrikaanse state en die Soedan. Die Ivoorkus en Senegal word in 1960 die eerste Wes-Afrikaanse state om groot internasionale senders te ontvang. Daar word in 1961 by Ejura 'n begin gemaak met die kortgolfsendersentrum van Ghana en soortgelyke planne in dieselfde jaar deur Nigerië aangekondig. Guinee, Mali, Togo en Ethiopië is kort op die hakke van hierdie state met senders vir eie buitelandse dienste.

Die feit dat hierdie lande ten spyte van beperkte begrotings - al is die begrotings dan ook dikwels van buite aangevul, gewis nie altyd om liefdadigheidsoorwegings nie bereid was om die koste vir die bou en instandhouding van groot senders te onderneem, onderstreep opnuut die betekenis wat vandag in Afrika aan die radio geheg word. Met verwysing na hulp van buite, was dit ook Rusland wat President Sekou Toure se Radio Conakry in Guinee gefinansier het.

Die snelle ontwikkeling van die radio in Afrika het die Suid-Afrikaanse Republiek, wat deur Voss beskryf word as die land met die hoogsontwikkelde radiowese op die vasteland, beslis nie verbygegaan nie. So word die kortgolfsender- 
sentrum in 1956 by Paradys, naby Bloemfontein, aangepak en daar reeds sedert 1958 met twee senders van $20 \mathrm{kw}$. elk uitsendings op Afrika gerig. Suid-Afrika tree op 1 Mei vanjaar op volwaardige wyse toe tot die geledere van uitsaaiers na die buiteland wanneer, soos reeds vermeld, die eerste fase van sy uiteindelike wêreldwye kortgolfdiens oor twee van sy vier kragtige senders van $250 \mathrm{kw}$. elk van stapel gestuur word.

In sy insiggewende ontleding wys Voss voorts daarop dat met die opbou van die sendernet daar ook 'n verandering in die innerlike struktuur van die radio in Afrika gekom het. Eers was die radio ' $n$ aangeleentheid van die Europese bevolkingsdele. Programme is deur Europeërs vir Europeërs voortgebring en het oorwegend vermaaklikheid voorsien. Wanneer, soos in Brits-Wes-Afrika, programme vir naturelle uitgesaai is, het hulle 'n oorwegend Europese karakter gehad. Dit het alles verander met die uitbreek van die Tweede Wêreldoorlog. Om die radiopropaganda van vyandige lande teen te werk en die bevolking gedurig oor die oorlogstoestand in te lig, het veral die Britse regering hom in baie gebiede van die radio bedien. Die uitsendings is - vir die eerste maal in groot omvang - ook in die inheemse tale uitgesaai om 'n so groot moontlike bevolkingskring aan te spreek. Uit die aard van die saak is hierdeur ervaring versamel wat by die opbou van territoriale of nasionale radionette ná die oorlog terdeë benut is.

In hierdie tweede fase van die radio-ontwikkeling is dic behoeftes van die inheemse bevolking sterker in ag geneem. In lande met oorwegend Afrika-bevolkings word sedertdien 'n wesenlike deel van die programme in die inheemse tale en dialekte uitgesaai. Hulle bevat tradisionele volksmusiek en vertellinge, asook aanbiedings deur inheemse kunstenaars. Die uitsendings is in die algemeen nie meer net volgens die Europese voorbeeld nie, maar het ook 'n "Afrika-karakter" verkry.

Hoewel sekere onafhanklike state algaande die gebruik daarvan verminder - Swahili het Engels byvoorbeeld reeds in 1964 as amptelike taal in Zanzibar vervang - het Engels en Frans nog 'n groot en dikwels oorheersende aandeel in die radioprogramme van verskeie Afrikalande. Voss hou vol dat die Europese tale nog lank een van die belangrikste bindmiddele van hierdie state sal wees en nie net oor stamgrense heen as verbindingselement sal dien nie, maar ook steeds 
die kontak met die ander Afrikalande en met die res van die wêreld sal moontlik maak.

Onder diegene wat meen dat Engels en ander Europese tale uiteindelik uit Swart Afrika sal verdwyn, is professor H. J. J. M. van der Merwe, dekaan van die Fakulteit Lettere en Wysbegeerte aan die Universiteit van Suid-Afrika. Hy voorspel dat die lingua franca van die meeste van hierdie gebiede Arabies of hoogswaarskynlik Swahili sal wees en verklaar terselfdertyd dat in die voormalige koloniale gebiede Frans 'n groter uithouvermoë as Engels openbaar.

In Egipte en Libië asook in 'n paar Oos-Afrikaanse gebiede, soos die Republiek Somali en in die noorde van die Soedan, is die toestand uit 'n taaloogpunt reeds heeltemal anders. Hier speel Arabies en Somali in so ' $n$ mate 'n oorheersende rol dat die radioprogramme of in hulle geheel of 'n wesenlike deel daarvan in hierdie tale uitgesaai word. In die lande wat verskillende groot nasionale groepe huisves, bestaan daar gewoonlik twee of drie sendernette waaroor elke groep versorg kan word. Met die besluit om 'n spesiale Bantoe-sendernet te verskaf wat hom daartoe in staat stel om elk van sy sewe Bantoenasies in hulle eie taal te bedien, het die Suid-Afrikaanse Republiek ook op hierdie oplossing besluit.

Hoewel prakties die hele Afrikaanse kontinent al deur die radio ontgin is, was die ontwikkeling in die onderskeie lande vanselfsprekend nie naasteby deurgaans dieselfde nie. Byna elke land beskik oor 'n eie sendernet of minstens 'n eie radiostasie. Dit sou verkeerd wees om hieruit 'n ontwikkeling af te lei wat tot op groot hoogte met Europese maatstawwe gemeet kan word. In sekere gebiede is daar maar net 'n begin gemaak. Teen die huidige tempo van ontwikkeling behoort alle lande egter binne afsienbare tyd oor 'n goed-uitgeboude radionet te beskik.

Aan die spits van die ontwikkeling staan Egipte en die Suid-Afrikaanse Republiek. Daarna volg die ander NoordAfrikaanse lande en die Soedan. Onder die voormalige Britse gebiede en die huidige protektorate is die Wes-Afrikaanse lande die meeste ontgin, terwyl 'n paar van die Oos-Afrikaanse gebiede eers in die jongste jare aansluiting gevind het en die protektorate Betsjoeanaland, Basoetoland en Swaziland in der waarheid nou eers op radiogebied ontwikkel word.

Wat die protektorate betref, het Radio Swaziland vir die 
eerste keer op 18 April vanjaar uit Mbabane in Engels en Swazi begin uitsaai oor 'n mediumgolfsender van $10 \mathrm{kw}$. Die beplanning vir Radio Lesotho dui daarop dat hy oor ' $\mathrm{n}$ mediumgolfsender van $10 \mathrm{kw}$. en 'n kortgolfsender van $5 \mathrm{kw}$. programme in Engels en Suid-Sotho uit Maseru sal aanbied, terwyl 'n mediumgolfsender van $10 \mathrm{kw}$. op Gaberones beoog word vir die uitsendings in Tswana en Engels van Radio Botswana.

Betekenisvol vir die Britse praktyk was die feit dat die radio met uitsondering van die destydse Federasie van Rhodesië en $\mathrm{Njassaland}$ oral van die begin af op territoriale grondslag georganiseer is.

In teenstelling daarmee is in die voormalige Franse gebiede aanvanklik probeer om in ooreenstemming met die opvatting van Franse eenheid nie binne streekgrense te bly nie. Separatistiese strewes van afsonderlike gebiede het egter later 'n ander benadering vereis wat op sy beurt die radiobeplanning verander het. Dakar en Brazzaville beskik oor goedtoegeruste stasies terwyl in die orige gebiede - afgesien van die Ivoorkus en ook Tsaad en Niger - hoofsaaklik klein senders met onafhanklikwording voorhande was.

Die voormalige Belgiese Kongo het ' $n$ relatief goed-uitgeboude sendernet, terwyl in die Portugese gebiede, op twee belangrike uitsonderings na, die radio oor die algemeen tot onlangs toe nog in die eerste fase van sy ontwikkeling was. In Angola alleen was daar byvoorbeeld agtien afsonderlike stasies. Die belangrike uitsonderings is die sterk kommersiële stasie in Lourenco Marques en die nuwe kommersiële stasie wat naby die grens van Suidwes-Afrika op Sa da Bandeira in Angola opgerig is en ook oor besondere sendkrag beskik.

Die eerste aanduiding van 'n splinternuwe en veelbetekende verwikkeling in verband met die radiowese in Afrika het gekom toe 'n konferensie van radiohoofde van sekere Afrikastate op uitnodiging van Marokko van 23 tot 26 Mei 1960 in Rabat gehou is. Benewens Marokko was Ghana, Guinee, Libië, Tunisië en die Verenigde Arabiese Republiek verteenwoordig.

Die afgevaardigdes het twee besluite geneem. In die eerste het hulle hul "oortuiging van die Afrika-solidariteit in die radiowese" uitgedruk en die noodsaaklikheid bevestig van samewerking binne die raamwerk van 'n bestendige radioorganisasie van die onafhanklike Afrikastate. Die doel van 
so 'n Radio-unie vir Afrika sou wees om die uitruil van programme en die samewerking op die gebied van die radio en die televisie aan te voor en te verdiep, die belange van die radio-organisasies van Afrika te beskerm en deelname aan internasionale konferensies te koördineer. In die tweede besluit is die volgende drie komitees gestig: ' $n$ regs- en administratiewe komitee, 'n tegniese komitee en 'n komitee vir programuitruiling.

Tydens die eerste konferensie van die regs- en administratiewe komitee wat vanaf 18 tot 22 Oktober 1960 in Tunisië gehou is - Senegal, Gabon, Nigerië en die Somali-republiek was ook nou teenwoordig en Togo het ' $n$,,solidariteitstelegram" gestuur - ontvang die organisasie sy amptelike naam: „Union of National Radio and Television Organisations of Africa" (URTNA). En by geleentheid van die eerste konferensie van die tegniese komitee in Kaïro op 22 April 1961 besig 'n kabinetsminister van die Verenigde Arabiese Republiek, dr. Abdel Kader Hatem, die volgende veelseggende woorde in sy openingsrede voor die vergaderde afgevaardigdes van dertien lande: samewerking in die stryd teen die imperialisme moet as een van die gewigtigste take van URTNA beskou word.

Hoewel daar in een stadium oorweging daaraan verleen is om 'n eie radio-organisasie vir die Brazzaville- en Monroviagroep van Afrikastate afsonderlik van URTNA te laat funksioneer, is tot dusver daarin geslaag om die "solidariteit" onversteurd te laat en inter-Afrikasamewerking tussen die betrokke groepe lande te bewerkstellig.

\section{Radio-uitsendings na Afrika:}

Afrika in toenemende mate skyf vir wêreld se buitelandse uitsendings. - Rusland en Kommunistiese Sjina beskik oor grootste buitelandse dienste. - Uitsendings hang saam met politieke ontwikkeling. - Gebruik van inheemse tale bring nuwe aksent. - Afrika andermaal in kruisvuur van internasionale propaganda met toetrede van Kommunistiese omroepe in 1958. - Afrika-uitsendings van Westerse, Midde-Oosterse en Oosterse lande - Afrika-uitsendings van lande agter Ystergordyn. - Moontlike luistertal en uitwerking op die openbare mening in Afrika.

Afrika word in toenemende mate 'n belangrike skyf vir 
die buitelandse uitsendings van 'n menigte lande van die wêreld.

Daar is reeds ten aanvang daarop gewys dat 37 lande altesame $1,436 \frac{1}{2}$ uur lank per week in 24 tale na Afrika uitsaai. Ook is die feit vermeld dat kommunistiese lande, met Rusland en Sjina aan die spits, vir nie minder nie as 336 van hierdie uitsaai-ure verantwoordelik is. Indien voorts daarop gelet word dat die 37 lande meer as die helfte van alle lande verteenwoordig wat oor buitelandse dienste beskik - daar is 73 sodanige lande wie se gesamentlike buitelandse uitsendings 12,866 uur per week beloop - word die belangrikheid waarmee Afrika deur die buitewêreld bejeën word, nog skerper afgeteken.

Met verwysing na buitelandse uitsendings in die algemeen, vestig die BBC in sy jongste jaarboek die aandag op 'n veelbetekenende feit. Tot in die vyftiger jare nog het die BBC self koning gekraai as die radio-orgnisasie met die meeste buitelandse uitsendings. Danksy veral die geweldige toename in hulle uitsendings na Afrika en Asië, het Rusland en Kommunistiese Sjina nou die voortou geneem en beskik hulle onderskeidelik oor die wêreld se grootste en tweede grootste buitelandse dienste, gemeet aan die aantal uitsaai-ure per week. Die Verenigde State van Amerika is derde en Brittanje vierde. Radio Moskou saai tans in 64 tale, insluitende 10 Sowjettale, 1,344 uur per week na die buiteland uit, terwyl Radio Peking se buitelandse uitsendings weekliks 937 uur beloop. Die „Voice of America” maak van 38 tale in sy buitelandse uitsendings gebruik wat weekliks 873 uur in beslag neem, en die BBC saai iedere week 639 uur lank in 41 tale na die buiteland uit.

Om meer in die besonder tot Afrika terug te keer, sluit die 37 lande wat na Afrika uitsaai die volgende in: 18 Europese lande, met inbegrip van Oos-Europese state en Rusland self; 8 Midde-Oosterse en Oosterse lande, en die V.S.A. en Kanada. Die 24 tale word saamgestel uit agt Afrikastate - insluitende Afrikaans en Zoeloe - vier Oosterse en twaalf Europese tale. Onder die Europese tale wat deur die onderskeie lande in hulle uitsendings gebruik word, kom Engels en Frans die meeste voor, terwyl Arabies en Swahili voorrang geniet onder die inheemse tale.

Harold Voss wys daarop dat die radio-uitsendings na 
Afrika van die begin af ten nouste saamgehang het met die algemene politieke ontwikkeling. Ter vestiging van die bande met Empire en Commonwealth het die BBC ná jarelange proefuitsendings in Desember 1932 van die kortgolfsentrum Daventry met die Empire-program begin. Frankryk het hom ook reeds sedert die begin van die dertiger jare oor die "Radio Colonial" tot sy kolonies in die hele Afrika gewend.

Deur die optrede van Italië het die uitsendings na Afrika reeds heel gou 'n nuwe aksent ontvang. Sy groot sentrum wat in 1932 in Bari voltooi is, het gaandeweg die basis geword van 'n groot aangelegde propagandaveldtog wat nie slegs in Europese tale nie, maar ook in toenemende mate in Arabies gevoer is. Die uitsendings het in so 'n mate toegeneem dat die BBC gedwonge was om die beginsel wat hy jare lank volgehou het, naamlik om net in Engels uit te saai, prys te gee en van 3 Maart 1938 ook nou uitsendings in Arabies uit te stuur. Ondertussen het Duitsland met 'n omvattende buitelandse diens begin wat reeds in 1939 programme meer as 70 uur lank per dag vir 'n groot deel in vreemde tale uitgesaai het. In dieselfde jaar was meer as elf persent van die uitsendings uit Duitsland vir Afrika bestem en het hy teen die einde van die jaar ook nog 'n spesiale program in Arabies bygevoeg wat daagliks ongeveer twee uur geduur het. Ook die Japanese radio het reeds op hierdie tydstip programme in Arabies aangebied.

Ooreenkomstig die destydse verhoudings, het die radiouitsendings hulle in eerste instansie tot die blanke bevolking in Afrika gerig, veral Suid-Afrika, terwyl onder die nieblanke bevolkingsgroepe hoofsaaklik Arabiere en Berbers in Noord-Afrika aangespreek is. Daar kan begryp word tot watter crescendo die Afrika-uitsendings gedurende die Tweede Wêreldoorlog opgevoer is toe die radiostasies van die vegtende moondhede in stygende mate hulle propaganda-uitsendings oor die hele kontinent tot in Suid-Afrika uitgestraal het.

Ná 1945 was die radio-uitsendings na Afrika aanvanklik 'n monopolie van die westerse magte. Sedert 1958 en 1959 egter het die hele vasteland opnuut in die volle kruisvuur van die internasionale radio-propaganda beland. In die lente van 1958 het naamlik ook die Sowjetunie met spesiale radio-uitsendings vir Afrika begin. Radio Peking en Radio Praag het teen die einde van Augustus en die middel van Oktober 1959 gevolg 
en intussen saai ook die meeste ander Oos-Europese lande self Afrikaprogramme uit.

Dit sou vanselfsprekend 'n onbegonne taak wees om in die bestek van hierdie referaat die huidige Afrika-uitsendings in besonderhede in oënskou te neem. Daar word gevolglik volstaan met kort verwysings na sommige daarvan.

Die BBC gaan steeds voort met sy uitsendings na alle dele van Afrika en bedien hom hoofsaaklik in sy programme vir hierdie vasteland van Engels, Frans, Arabies, Swahili, Hausa, Urdu, Hindi en Somali. Onthou sal word dat daar ook 'n tydperk was - Mei 1939 tot 7 September 1957 - dat hy in Afrikaans na Suid-Afrika uitgesaai het. Dit was opvallend dat hy ná die vrywording van voormalige Franse kolonies sy uitsendings in Frans na Wes- en Sentraal-Afrika eers van 1 uur tot $3 \frac{1}{2}$ uur per week en in Februarie 1961 tot $24 \frac{1}{2}$ uur per week vermeerder het. Die BBC se invloed in Afrika is noodwendig verminder toe 'n aantal lande algaande die regstreekse herleiding van sekere van sy nuusdienste en ander programme gestaak het. Suid-Afrika was kort ná 1948 die eerste van hierdie lande, wat ook Ghana, Nigerië, Kenia, Tanzanië en Malawi insluit, en Rhodesië tot op datum die laaste. Met die beplande ingebruikname van sy heruitsendingsentrum op Ascension-eiland in Junie vanjaar, hoop die BBC om sy huidige opvangsprobleme in Afrika - sy uitsendings word tans in verskeie streke beswaarlik op transistorstelle opgevang die hoof te bied.

Sedert die voltooiing van sy reuse-sendsentrum in Greenville, Noord-Carolina - met senders van sowel $250 \mathrm{kw}$. as $\mathbf{5 0 0}$ $\mathrm{kw}$. is dit van die grootste sentrums ter wêreld - word die spesiale Afrikaprogramme van die "Voice of America" nog helderder as vantevore gehoor. Net soos die BBC het die „Voice of America” ook nou 'n radiostasie in Monrovia, Liberië. In teenstelling met die BBC se heruitsendingstasie wat oor geen uitermate sterk sender beskik nie, kan Amerika ook hier reken op sendsterkte van soveel as $250 \mathrm{kw}$. Hy besit natuurlik reeds geruime tyd 'n stasie in Tangiers. "Voice of America"programme vir Afrika is ook al van München en Salonika uitgestraal. Onder sy verklaarde doelstelling „om 'n groter begrip van die Verenigde State by die volkere van die wêreld te bevorder en om internasionale verhoudings van samewerking te verstewig" saai die "Voice of America" in Engels, 
Frans, Arabies, Hausa en Swahili na Afrika uit. Sy Arabiese programme het in 1960 reeds $52 \frac{1}{2}$ uur per week beloop en die hoof van die Amerikaanse Inligtingsdiens het kort daarna as beleid aangekondig dat Amerikaanse radio-bedrywigheid veral in Afrika en Latyns-Amerika nog verder versterk moet word.

Kanada het ook daaglikse uitsendings na Afrika en maak van Engels en Frans gebruik.

'n Tweetal lande wie se Afrika-uitsendings aandui dat hulle, soos verwag kan word, noue bande met hierdie vasteland wil behou, is Frankryk en Portugal. Ook die Franse radio beskik vir sy buitelandse diens oor ' $n$ sterk sendsentrum in Afrika. Teen 1960 word reeds 'n groot aantal programure aan Wesen Sentraal-Afrika en in die besonder aan Madagaskar, die Comoro's, Somaliland en Réunion gewy. Aan die einde van dieselfde jaar word ook Arabiese programme vir Noord-Afrika ingestel, terwyl 'n groot deel van die Franse se binnelandse programdiens, „Paris Inter (France I)" na Afrika oorgedra word. Die buitelandse en internasionale dienste van die Portugese staatsradio wend hulle vanselfsprekend tot die oorsese provinsies van Portugal. In 1960 is omtrent 88 uur per week na Mosambiek en Angola uitgesaai en nog 70 uur na Guinee (Portugees) en die Kaapverdiese eilande. Die enigste vreemde taalprogram is $5 \frac{1}{2}$ uur lank per week vir Kenia, die destydse Tanganjika, Uganda en Suid-Afrika in Engels aangebied. Vandag word ook programme in Frans na Afrika uitgestraal.

Alvorens vlugtig na Rusland, Kommunistiese Sjina en sekere Oos-Europese state verwys word, kan vermeld word dat die volgende lande onder diegene uit Wes-Europa, die Midde-Ooste en die Ooste is wat buitelandse uitsendings na Afrika rig en hulie maak onder andere van die tale gebruik wat in hakies aangedui word: Wes-Duitsland, wie se „Deutsche Welle" ook 'n sterk heruitsendingstasie in Rwanda het (Duits, Engels, Frans, Amharies, Arabies, Swahili en Hausa); Nederland (Nederlands, Afrikaans, Arabies, Engels en Spaans); Italië (Italiaans, Engels, Somali en Arabies); Spanje (Spaans, Frans en Arabies); Switserland (Duits, Frans, Italiaans, Engels, Arabies en Portugees); Swede (Sweeds, Engels, Duits en Frans); Indië, wat hom in 17 tale tot die buitewêreld wend ('n groot aantal Indiese tale, Engels en Swahili); Israel (Yiddish, Engels, Frans, Arabies en Swahili), en Japan, wat alte- 
same in 23 tale na die buiteland uitsaai (Swahili, waarin hy eers vanaf 1 April 1964 begin uitsaai, Japanees, Frans, Engels en Arabies).

Daar is reeds daarop gewys dat Rusland sy uitsendings na Afrika tot nie minder nie as $133 \frac{1}{2}$ uur per week vermeerder het. Terselfdertyd het hy in Januarie 1965 'n kragtige nuwe mediumgolfstasie naby Kharkov vir uitsendings na Afrika in gebruik geneem. Dit is veelbetekenend dat die addisionele tale wat hy by sy Afrika-repertorium gevoeg het almal inheemse tale is. Een daarvan is Zoeloe wat vanaf 18 Mei 1964 'n plek in die Russiese uitsaai-rooster gevind het. Die elf tale waarin Radio Moskou hoofsaaklik na Afrika uitsaai, is Engels, Frans, Portugees, Italiaans, Arabies, Amharies, Bambara, Hausa, Lingala, Somali en Swahili. Hieruit blyk duidelik dat die Russe op verre na van die meeste inheemse Afrikatale gebruik mak van alle buitelandse dienste wat uitsendings op Afrika rig.

Anders as in die geval van Radio Moskou, konsentreer Radio Peking tot op groot hoogte op Europese tale gedurende die 56 uur wat hy weekliks na Afrika uitsaai. Engels, Frans, Portugees en Kantonees - laasgenoemde bestem vir die Sjinese bevolking in Suid-Afrika, Madagaskar en Mauritius - is die tale van sy voorkeur vir hierdie vasteland, met Engels as die besondere gunsteling. Dit is alombekend dat Radio Peking waarskynlik die sterkste sender vir uitsendings na Afrika gebruik. Hierdie sender, versterk deur 'n heruitsendingstasie in Guinee, kan selfs op transistorstelle gehoor word en sy ontvangs op kortgolf is dikwels beter as plaaslike stasies op mediumgolf. Radio Peking het hom sodanig in Afrika ingegrawe dat hy 'n verteenwoordigende diskoteek opgebou het van inboorlingmusiek uit selfs die primitiefste Afrika-buurtes. In die nuusdienste, wat tot twintig minute duur, word behoorlik teen die ,kapitaliste" te velde getrek. Maar oor propaganda-veldtogte, skeldtaal en belastering in die Afrika-uitsendings word aanstons gesels.

Ander uitsendings wat spesiaal op Afrika gerig word van agter die Ystergordyn, kom onder meer uit Boelgarye, TsjeggoSlowakye, Oos-Duitsland, Pole en Roemenië. Die Boelgaarse staatsradio saai saans uit Sofia na Afrika uit in Frans en Engels; Radio Praag het gereelde uitsendings in Arabies, Engels, Frans en Swahili; Oos-Duitsland het daagliks drie uitsendings in Swahili en saai ook in Duits, Frans, Engels en 
Arabies na Afrika uit; Radio Warschau bied vier nuusdienste in die aand om die beurt in Frans en Engels aan, terwyl Radio Boekarest in Frans en Engels uitsaai.

Die vrae ontstaan vanselfsprekend in watter mate na hierdie uitsendings geluister word, watter uitwerking hulle op die openbare mening in Afrika het en of die uitsendings van buitelandse omroepe meer ingang vind en 'n groter luistertal lok as plaaslike programme.

Ofskoon daar in die meeste Afrikalande nog min omvattende luisteropnames onderneem is, dui alle beskikbare gegewens daarop dat voorkeur normaalweg aan die eie plaaslike stasie gegee word, veral wanneer plaaslike gebeurtenisse en die plaaslike tale en dialekte genoegsaam in aanmerking geneem word. 'n Landswye opname in Suid-Afrika in 1963 het byvoorbeeld aan die lig gebring dat 'n uiters geringe persentasie van die plaaslike Bantoes na buitelandse uitsendings luister en die oorweldigende meerderheid op die programme van die SAUK se Radio Bantu inskakel. 'n Opname in Ghana in 1964 het, volgens die Londense korrespondent van die Johannesburgse "Star", Radio Ghana eerste op die gewildheidsleer geplaas, daarna die naburige Radio Nigerië, toe die BBC en die „Voice of America", en eers 'n hele paar sporte laer Moskou, Peking, Frankryk en Kairo.

Harald Voss maak die interessante waarneming dat indien uitsendings van nie-Afrikalande en veral stasies van die Oostelike blok met 'n besliste invloed gekrediteer moet word, dit toe te skryf is aan die feit dat ' $n$ deel van die elite en van die studente onder die gereelde luisteraars na hierdie programme is. Albei hierdie groepe wat in die huidige Afrikagemeenskap 'n gewigtiger rol as in Europa speel, word juis deur die stasies van agter die Ystergordyn aangespreek. Hierby sou beslis ook plaaslike politieke agitators gevoeg kon word wie se ore voortdurend gespits is op die „boodskappe" van hierdie omroepe. Vir die toekomstige ontwikkeling is dit ook van betekenis dat verskeie kommunistiese lande gemoeid is om soos in Guinee, Ghana, Tanzanië, Kenia en die Somalirepubliek deel te hê aan die opbou van die Afrika-uitsaaistasies.

Ten opsigte van die reaksie in Afrika van uitsendings uit die Oos-Europese satellietlande, verwys ' $n$ berig in die Johannesburgse „Star" van 8 Augustus 1962 na die aanspraak van Radio Praag dat sy gereeldste luisteraars in Ghana en Nigerië 
is met Suid-Afrika, Sierra Leone, die destydse Tanganjika en Ethiopië die volgende op die lys.

Wat die invloed van Frankryk en die BBC betref, wys Voss op voordele wat hulle geniet deur van hulle programme regstreeks deur Afrikalande te laat uitsaai. Soos reeds aangetoon, het hierdie voordele veral in die geval van die BBC aansienlik verminder.

'n Buitengewoon insiggewende ontleding van die moontlike invloed in Afrika van die buitelandse uitsendings van uitsaaistasies soos Radio Moskou en Radio Peking, asook van sekere Afrika-omroepe, het op 27 Junie 1965 in die invloedryke "London Sunday Times" verskyn. Geskryf deur die koerant se verteenwoordiger in Nairobi, John Henderson, bevat die artikel ook 'n besondere pluimpie vir die objektiewe gehalte van die nuusuitsendings in die SAUK se huidige Afrikadiens en verklaar hy dat Suid-Afrika reeds in Oos-Afrika 'n voorsprong op Moskou en Peking behaal het in die steeds verskerpende oorlog-in-die-lug.

Oor die betrokke nuusuitsendings skryf hy: „The South African Broadcasting Corporation is a comparative newcomer to the radio propaganda war, so far as East Africa is concerned... The news broadcasts in English are gaining in reputation for accuracy and objectivity. A growing number of East Africans are tuning in to them because the BBC overseas service does not come in powerfully or clearly enough for transistor radio reception, and because they no longer trust radio bulletins put out by their Government-controlled local stations".

In 'n skerp-kritiese beskouing van die programinhoud van die uitsendings van Radio Peking, verklaar hy dat hierdie omroep sy propaganda-idees drasties sal moet wysig indien hy enigsins in Afrika hond haaraf wil maak. Van meer as 'n honderd Bantoes wat in Nairobi ondervra is, het nie 'n enkele na Radio Peking geluister nie. Die programme is net eenvoudig te vervelig en allermins gerig op die belangstellingsveld van die plaaslike bevolking. Volgens Henderson kan Radio Peking veel gaan leer by Radio Kairo wie se programme geskryf en aangebied word deur persone afkomstig uit die teikengebied en wat gevolglik ook 'n groot luistergehoor in Oos-Afrika geniet.

Samevattend besluit hy: „The radio war in East Africa 
today is between Cairo and Johannesburg, with the BBC fussing around at the edges. Peking and Moscow have still to make their mark".

„Die Vaderland" haal op 3 Augustus 1965 United Press International se bevindings aan van die invloed van radiouitsendings in Afrika. Hierdie belangrike nuusorganisasie se opsomming van die situasie dui Rusland en Kommunistiese Sjina, van buite, en die Verenigde Arabiese Republiek en SuidAfrika, van binne op die twee eindpunte van die vasteland, as die groot mededingers om die "siel" van Afrika aan en vervolg: „Op die oomblik word die louere blykbaar weggedra deur Kairo en Suid-Afrika, hoofsaaklik omdat albei skynbaar ' $n$ beter begrip van Afrika se behoeftes het as of die Russe of die Kommunistiese Sjinese".

United Press het ook heelwat te sê oor die inhoud van Radio Peking sc uitsendings. Afrika-luisteraars stel net eenvoudig nie belang in die langdradige polemiese hoofartikels wat woordeliks deur Peking uit die "People's Daily" aangehaal word nie. En nog minder stel hulle belang in die nuwe toesprake deur lede van die Sjinese Afro-Asiatiese solidariteitskomitee wie se name niks vir die gewone naturel beteken nie.

Volgens United Press is Radio Moskou subtieler met sy uitsendings na Afrika en wen hy meer "ore”, hoewel sy gelokaliseerde programme egter nie kan kers vashou met dié van òf Kairo of Suid-Afrika nie, ofskoon dit baie beter is as Radio Peking se pogings.

Met betrekking tot die uitsendings van die SAUK se Afrikadiens, wat tans nuusbulletins en nuuskommentaar in Engels, Afrikaans, Frans, Portugees en Zoeloe insluit, verklaar United Press: „Daar word min pogings tot regstreekse propaganda aangewend en naturelle-luisteraars het verbasing uitgespreek oor die objektiwiteit van die nuusuitsendings".

\section{Die idoologiese propaganda-oorlog:}

Uitsendings wat die blanke in Afrika beswadder en on ware en opruiende materiaal bevat. - Regsreëls van die ou Volkerebond en die V.V.O. ten opsigte van internasionale uitsendings. - Verkragting van hierdie reëls deur Afrikastasies en buitelandse dienste van Kommunistiese lande. 
'n Ontstellende aspek van radio-uitsendings in en na Afrika is die onverantwoordelike en onbeteuelde beswaddering van die blanke van hierdie vasteland deur die buitelandse dienste van kommunistiese lande en sekere Afrikastasies, en die skaamtelose onwaarhede wat deur hierdie omroepe oor lande soos Suid-Afrika, Portugal en Rhodesië kwytgeraak word. In die stortvloed ideologiese propaganda word dikwels ook nie geskroom om die swartman op te rui om met wapengeweld teen die witman op te staan nie.

As belangrike kommunikasiemiddel was die radio uit die staanspoor bestem om goedgesindheid en onderlinge begrip tussen volkere te bevorder. Ten volle bewus van die invloed van radio-uitsendings en die verreikende gevolge van ' $n$ verkragting van hierdie beginsel, het die ou Volkerebond reeds regsreëls ten opsigte van internasionale uitsendings opgestel tydens ' $n$ internasionale konferensie in Genève in 1936.

Drie van die vernaamstes hiervan lui:

Alle uitsendings wat daarop bereken is om die bevolking van 'n ander land op te sweep om die binnelandse orde en veiligheid te ondermyn, word verbied; geen buitelandse uitsendings mag oorlog in ' $n$ ander land teen 'n derde land stook nie; alle uitsendings wat die goeie internasionale verhoudings versteur deur valse inligting uit te saai, word verbied.

Hierdie ooreenkoms is in 1954 deur die V.V.O. bekragtig met byvoeging van die volgende:

„Each contracting State shall refrain from radio broadcasts that would mean unfair attacks or slanders against other people anywhere, and in so doing, to conform strictly to an ethical conduct in the interest of world peace by reporting facts truly and objectively and to provide that each contracting party shall not interfere with the reception, within its territory, of foreign radio broadcasts".

Hoe min sekere radiostasies hulle aan ooreenkomste van hierdie aard steur, sal duidelik blyk uit enkele voorbeelde van uitsendings wat in Suid-Afrika opgevang is.

Radio Kairo, wat altesame in 26 tale uitsaai en in 14 na Afrika, het pas drie jaar gelede met uitsendings in Suid-Sotho 
begin - hy is die enigste uitsaaistasie buite Suid-Afrika en Basoetoland wat hierdie taal gebruik - toe 'n Bantoe-omroepster met 'n benydenswaardige Butha Buthe-breiklank onder meer die volgende woorde in Suid-Sotho gebesig het: „Die leiers van maAfrika het verklaar dat die prys vir 'n oog 'n oog is; die prys van die lewe van die maAfrika is die bloed van die witman in Suid-Afrika..."

Radio Ghana se reuse-senders by Ejura het dikwels gedurende die afgelope paar jaar boodskappe van die sogenaamde Radio Freedom Fighters aan Afrika uitgedra. Op 'n aand het die boodskap soos volg gelui: „Long live our Africa... Wake up children of Africa... Take the arms which are given by our true friends and fight the White settlers. Throw them to the sea. Death to the White dogs. Africa is ours and we want her back now. We will crush Verwoerd and Salazar".

Dit is van uitsendings soos hierdie dat die "Natal Mercury" in 'n hoofartikel op 8 Desember 1960 geskryf het: „Radio Cairo's socalled Freedom talks and news services are so scurrilously abusive of Whites in Africa and so moronically stupid that only the pawns of Communism are likely to be influenced by them".

Dit mag wel tot op sekere hoogte so wees, maar daar is stellig ook talle onontwikkeldes wat nog buite die Kommunisme staan wat hulle ore sal spits by die aanhoor van sulke woorde.

Radio Tanzanië, wat naas Radio Bantu en Radio Moskou die enigste omroep is om ook in Zoeloe uit te saai, het in Mei 1964 die nie-blanke bevolking van Suidwes-Afrika verras toe hy uitsendings in Herero op hierdie gebied begin rig het. Soos gebruiklik in verskeie van sy uitsendings, het hy nie nagelaat om te velde te trek teen die blanke van Suid-Afrika nie. Die verbanne A.N.C. het in 1963 ' $n$ spreekbuis in Radio Algiers gevind wat elke Vrydagaand spesiale boodskappe na. mens hom uitgesaai het.

Pas verlede maand nog het Radio Zambië 'n opskudding verwek toe hy naturelle in Rhodesië opgesweep het tot verkragting, moord en brandstigting. Onder die verbanne swart Rhodesiërs wat vanuit Livingstone uitgesaai het, was die onderpresident van die verbode Z.A.P.U., James Chikerema, wat onder meer in Shona die volgende beroep op swart Rhodesiërs gedoen het: „Vorm groepe en gaan snags uit na die blanke plase en sny die tabak af wat geplant is. Maak die boer dood. 
Doen alles, gaan voorwaarts, maak dood en veroorsaak chaos in Rhodesië".

Benewens die terrein van die programme, is daar ook nog ' $n$ ander gebied in die radiowese wat deur die jonger Afrikastate op militante en ongedissiplineerde wyse betree word. Van hulle ignoreer die frekwensietoekennings wat uit Geneve aan hulle gemaak word en saai soms op golflengtes uit wat aan ander lande toegeken is.

Wat die gif-propaganda van kommunistiese uitsaaistasies van oorsee betref, kan volstaan word met drie kort aanhalings.

Pas op 30 Maart vanjaar nog, verklaar Radio Moskou: "The Soviet Solidarity Committee for Africa on behalf of the Soviet public has repeatedly spoken in support of the struggle of the peoples of South Africa, Zimbabwe and South West Africa for freedom and complete independence. May the fighters for the freedom of Angola and Mozambique, and the patriots who languish in the prisons of South Africa and Rhodesia, know that we are on their side in the great struggle for a full liberation of the African continent".

'n Uitsending van Radio Berlin International (Oos-Duitsland) op 30 Julie 1965 lui onder meer soos volg: „Verwoerd's spokesman has on several occasions stated that South Africa has the necessary potentials to make nuclear weapons, and the Verwoerd regime has bought military planes with the hope of carrying and dropping atom bombs. Last year the G.D.R. committee for Afro-Asian solidarity exposed a secret agreement which exists between the Imperialist West German Federal Republic and the Republic of South Africa in military and economic fields. This brings the danger of nuclear war right on to the doorstep of the African Continent".

Radio Praag lewer op 10 Augustus 1965 die volgende kommentaar oor die hofsaak in verband met die Cinderellagevangenis: „Even though Cinderella is just one of South Africa's prisons, it is absolutely clear that there are many such Cinderella prisons and an increasing number of people have come to realise that in fact all South Africa is nothing but a big Cinderella prison".

5. Die S.A.U.K. en sy Bantoe- en buitelandse dienste:

SAUK beskik oor hoogs-ontwikkelde radiowese op vaste- 
land. - Uitbreidings neem groot afmetings aan. - Radio RSA beplan uitsendings dertig uur daagliks in nege tale na verskeie wêrelddele. - Vasteland van Afrika eerste teikengebied. - Doelstellings van Radio RSA. - Reusereaksie op programme van Radio Bantu. - Programinhoud en doelstellings van ses programdienste in sewe Bantoetale.

Daar is reeds daarna verwys dat Harald Voss Suid-Afrika in „Rundfunk und Fernsehen in Afrika" uitsonder as die land met die hoogs-ontwikkelde radiowese op die vasteland van Afrika.

In die afgelope vier jaar veral het die ontwikkeling reuseafmetings aangeneem en is uitbreidings teen 'n buitengewoon snelle tempo onderneem. Tot aan die einde van 1961 het die SAUK oor drie binnelandse programdienste beskik - Afrikaans, Engels en Springbokradio - en is Bantoeprogramme, prakties gesproke, as deel van eersgenoemde twee dienste uitgesaai. Gedurende daardie jaar is die Hertzog-toring in Johannesburg voltooi en met ingang 1962 is vyf verskillende programme gelyktydig daarvandaan aangebied: die drie bestaande programme, plus Suid-Sotho en Zoeloe.

Soos die aantal FM-maste eers in stedelike en daarna in minder digbevolkte gebiede verrys het, is nuwe programdienste ingestel in Noord-Sotho, Tswana en Xhosa. In 1964 en 1965 onderskeidelik is ook die tweetalige FM-streekdienste in Afrikaans en Engels, Radio Hoëveld en Radio Goeie Hoop, bygevoeg en 'n deurnagdiens, wat op FM uitsaai in die streek en oor kortgolf dwarsdeur die land van middernag tot vyfuur soggens, op 1 September 1964 ingestel. 'n Venda/Tsongadiens, wat voorlopig nog slegs twee uur lank per dag oor mediumgolf uitsaai solank daar gewag word op die voltooiing van die FM-netwerk in die besondere teikengebied, het in 1965 met uitsendings begin.

Op hierdie manier is die destydse drie binnelandse dienste van die SAUK in minder as vier jaar na elf dienste uitgebrei. Mettertyd sal nog 'n spesiale FM-diens vir Natal ingestel word en wag die deeltydse Venda/Tsongadiens. Wanneer dit sou gebeur, sal die SAUK se binnelandse netwerk, wat aanvanklik drie dienste gehad het wat vyftig uur per dag uitsaai, dertien dienste hê wat gesamentlik ver oor die tweehonderd uur per 
dag op die lug is.

Die instelling van FM het vir 'n groot verbetering in die gehalte van radio-ontvangs in Suid-Afrika gesorg. 'n Luisteraar wat binne 60 na 200 myl van die naaste FM-sender woon, na gelang die topografie, kan sonder steuring vier-en-twintig uur lank inluister ongeag die weerstoestande of hoeveel steu. rings van apparate daar in sy omgewing is.

Samevattend het die voorsitter van die SAUK se Beheerraad, dr. P. J. Meyer, in Maart vanjaar daarop gewys dat die toename in luisteraars gedurende die dertigjarige bestaan van die SAUK saamval met die uitbreiding in die programdienste. Teen die einde van 1965 was daar 1,368,660 lisensiehouers, wat die moontlike luistertal na sewe miljoen verhoog het. Hulle besit meer as 'n kwartmiljoen ontvangstoestelle. In verhouding het die grootste toename onder die Bantoe voorgekom, waar die aantal lisensiehouers gemiddeld met 25 persent die afgelope twee jaar gestyg het.

Die omvangryke radio-bedrywigheid in Suid-Afrika het gewis nie slegs op die oomblik met binnelandse uitsendings te make nie. Soos voorheen vermeld, word die eerste fase van wat beplan is om eerlang Suid-Afrika se wêreldwye kortgolfdiens in nege tale te wees, op 1 Mei van stapel gestuur. Aangesien Radio RSA - Die Stem van Suid-Afrika - soos die SAUK se buitelandse diens homself deurgaans aan Afrika en die wêreld sal voorstel - nou verband hou met die radioprentjie van die hele Afrika en 'n wesenlike uitwerking daarop kan hê, word kortliks by die ontwikkeling, omvang en oogmerke daarvan stilgestaan. Met die oog daarop dat uitsendings in Suid-Afrikaanse Bantoetale en ook in Engels van buite Suid-Afrika spesifiek tot die Bantoes van hierdie land gerig word, verwys ons ook ten besluite na die SAUK se Radio Bantu en die reuse-reaksie by ons Bantoe-luisteraars op die programme van sy ses afsonderlike programdienste.

Om by Radio RSA te begin wie se stem, die Stem van SuidAfrika, bestem is om 301 uur lank per dag in nege tale om die aardbol te weerklink - in Afrikaans, Engels, Duits, Nederlands, Frans, Portugees, Spaans, Chinyanya en Swahili.

Dit is reeds vlugtig genoem dat die SAUK sedert 1958 'n beperkte Afrikadiens uitsaai oor twee senders van $20 \mathrm{kw}$. elk. Die diens het tot die middel van 1964 slegs bestaan uit die herleiding van sekere van die SAUK se binnelandse programme 
met die bedoeling noofsaaklik om Suid-Afrikaners in gebiede benoorde Suid-Afrika in voeling met hulle vaderland te hou. Die programme is op geen spesifieke teikengebied gerig nie en was nie daarop bereken om spesiaal inligting en feite oor Suid-Afrika aan die buiteland oor te dra nie.

Die aankondiging dat vier kragtige kortgolfsenders van $250 \mathrm{kw}$. elk aangekoop word en die Regering ' $\mathrm{n}$ omvattende buitelandse diens aan die SAUK toevertrou, het hierdie posisie ingrypend verander. Die eerste stap in die vestiging van die toekomstige Radio RSA het bestaan uit die re-organisasie van die bestaande Afrikadiens as tussentydse maatreël totdat die nuwe senders en die lugdrade wat dit vir hulle moontlik sou maak om verskillende dele van die wêreld te bereik, beskikbaar sou word. Gekeurde programme uit die Engelse en Afrikaanse dienste is behou, maar daarbenewens ook spesiale programme in Afrikaans, Engels, Frans, Portugees en Zoeloe aangebied.

Die nuwe sendstasie op Bloemendal, naby Meyerton, is op 27 Oktober 1965 deur die Eerste Minister geopen en die eerste van die $250 \mathrm{kw}$-senders in werking gestel. Met die tweede sender ook in gereedheid gebring, is die weg gebaan vir die aanvang op 1 Mei van die eerste fase in Suid-Afrika se program van omvattende buitelandse uitsendings.

Die vasteland van Afrika is tot op groot hoogte Radio RSA se eerste teikengebied en programme word onder andere gerig op Kenia, Uganda, Tanzanië, Rhodesië, Zambië, Malawi, Nigerië, Ghana, die Kongo, Kameroen, Gabon, Niger, Mosambiek en Angola. Daar is ook 'n algemene Afrikaprogram en daar word reeds uit die staanspoor elke aand 55 minute lank in Engels na die Verenigde Koninkryk en Europa uitgesaai. Die tale wat aanvanklik gebruik word, is Afrikaans, Engels, Frans, Portugees en Zoeloe.

'n Eerste uitbreiding word vir 1 September vanjaar beoog wanneer gehoop word om reeds 55 minute lank per dag uitsendings in Engels na die V.S.A. en Kanada te rig. Dit word voorts in die vooruitsig gestel om vanaf 1 Desember, benewens Engelse uitsendings, ook programme in Portugees, Frans, Spaans, Duits en Nederlands na Europa uit te saai. Ten opsigte van uitsendings na Afrika, sal Swahili-programme al hoogswaarskynlik teen hierdie tyd die Zoeloeprogramme vervang het. 
Sodra die beplande uitbreidings afgehandel is, sal die uitsendings daagliks soos volg verloop:

$1.30-5.30 \mathrm{vm}$. (S.A. tyd): vier uitsendings van 55 minute elk in Engels na die V.S.A. en Kanada.

$1.30-4.30$ vm. (S.A. tyd): (d.w.s. gelyktydig met die eerste): twee uitsendings in Spaans en een in Portugees na Latyns-Amerika.

$6.00-9.00 \mathrm{vm}$. (S.A. tyd): dertien uitsendings van vyftien minute elk na Afrika in Afrikaans, Engels, Frans, Portugees, Swahili en Nyanya.

$12.00-5.00 \mathrm{~nm}$. (S.A. tyd): Vyf uitsendings van vyf-en-vyftig minute elk in Engels na Indië en Pakistan, die Fillipyne en ander gebiede in Suidoos-Asië, Japan, Australië en NieuSeeland.

$5.00 \mathrm{~nm} .-1.30 \mathrm{vm}$. (S.A. tyd): Vyftien uitsendings van 55 minute elk na Afrika en Europa in Engels, Frans, Spaans, Nederlands, Duits, Portugees, Swahili en Chinyanya. Sekere van die uitsendings is op Europa en andere op Afrika gerig. Ook hier word gevolglik gebruik gemaak van sogenaamde „dubbelloop"-uitsendings.

Anders as in die geval met buitelandse uitsendings van kommunistiese lande en sekere van die Afrikastate, is Radio RSA allermins daarop uit om skoor te soek met enige volk of staat en om 'n oorlog-in-die-lug teen so 'n staat te ontketen. Terselfdertyd sou hy sy plig versaak indien hy nie, waar dit nodig mag blyk, valse aantygings teen Suid-Afrika op 'n waardige en beheerste wyse weerlê nie. Die SAUK se huidige beperkte Afrikadiens het reeds daarin geslaag om 'n heel besondere toon, ontdaan van histerie en berekende venyn, die etergolwe in te dra wat Afrika-naturelle duidelik verras en 'n etiket van betroubaarheid aan sy uitsendings gehang het. Radio RSA is voornemens om in die voetspore van sy voorloper te volg.

In die besonder is dit sy bedoeling om kennis en feitelike inligting oor die Republiek te versprei. Hy sal verwys na die bevolking-samestelling van Suid-Afrika, na die vrede en harmonie wat daar heers en die geleentheid wat aan elkeen gebied word om na sy eie aard tot volle wasdom te ontwikkel. $\mathrm{Hy}$ sal vertel van die ekonomiese krag en nywerheidspotensiaal van die land van sy prestasies en leierskap op wetenskaplike 
en sosiologiese gebied; van sy rykdom aan materiële en geestesgoedere en van sy natuurskoon.

By uitstek sal Radio RSA hom daarvoor beywer om 'n groter begrip te bevorder van ons land, sy probleme en sy mense. Hy sal steeds trag om vriendskapsbande in en buite Afrika te smee en om insig en minstens 'n nuwe benadering te kweek waar voorheen agterdog en vyandigheid bestaan het.

Benewens die veertig nuusbulletins per dag wat in die voltooide diens uitgesaai sal word, sal Radio RSA ook 'n verskeidenheid programme aanbied wat 'n panoramiese beeld gee van Suid-Afrika en sy mense.

Te oordeel na die reaksie wat reeds geruime tyd uit verskeie wêrelddele op die huidige beperkte Afrikadiens van die SAUK ontvang word - meer as 400 briewe is reeds in 'n enkele maand aan hom gerig en reaksies was, afgesien van Afrika, ook al afkomstig uit Europa, die V.S.A., Australië, NieuSeeland, Indië, Pakistan en Japan - behoort die helder stem van die omvattende Radio RSA op heelwat verwagte en onverwagte plekke ingang te vind. Veral sal dit sy strewe in Afrika wees, om te midde van talle verwarrende stemme, as 'n stem van geloofwaardigheid en gesag uitgeken te word.

Die suksesverhaal van Radio Bantu, die SAUK se ses programdienste in Zoeloe, Suid-Sotho, Xhosa, Noord-Sotha, Tswana en Venda/Tsonga, toon dat hy tot op groot hoogte in die behoeftes van plaaslike Bantoe-luisteraars voorsien.

Sy besondere gewildheid onder die Bantoes van die Republiek is op treffende wyse bevestig toe Suid-Afrika se nasionale leseropname in 1962 aangetoon het dat van alle Bantoes wat in daardie stadium op die radio ingeskakel het, nie minder nie as $86.5 \%$ gereelde luisteraars van Radio Bantu was. Ander het hoofsaaklik na die SAUK se ander programdienste en na Lourenco Marques geluister. 'n Landswye luisteropname in 1963 het aan die lig gebring dat daar reeds op daardie tydstip meer as 'n miljoen volwasse Bantoes was wat daagliks na die programme van Radio Bantu geluister het. Gedagtig aan die uitbreiding van die FM-netwerk en die aansienlike toename in luisteraarsreaksie sedert die vorige opnames, is daar alle aanduidings dat die tweemiljoen-kerf reeds bereik is.

Met verwysing na luisteraarsreaksie, het Radio Bantu gedurende 1965 meer as 1-miljoen 600,000 luisteraarsbriewe ontvang teenoor $1,274,695$ in $1964,699,433$ in 1963 en 332,302 in 
1962. Die maandelikse korrespondensiesyfer het vanjaar reeds die 200,000-kerf oorskry sodat die totale aantal briewe vir 1966 heelwat meer as tweemiljoen behoort te wees.

Hoewel Radio Bantoe se programdienste en sy FM-netwerk in eerste instansie op die Bantoe-bevolking van die Republiek ingestel is, was dit opvallend dat 1,138 briewe in Maart vanjaar uit Swaziland en 1,090 uit Basoetoland afkomstig was.

Indien daaraan gedink word dat die SAUK se uitsendings in Bantoetale slegs ses jaar gelede nog beperk was tot ' $\mathrm{n}$ paar daaglikse programme oor mediumgolf en 'n rediffusiediens na die Johannesburgse Bantoedorpe, dui die $72 \frac{1}{2}$ uur wat tans daagliks gesamentlik deur die ses programdienste uitgesaai word die omvangryke ontwikkeling aan wat sedertdien plaasgevind het.

Die onderskeie programdienste van Radio Bantu is op dié besondere deel van die land gerig waar daar 'n konsentrasie van lede van 'n bepaalde Bantoenasie aangetref word. Die Zoeloediens word byvoorbeeld gehoor in Natal en ' $n$ gedeelte van Transvaal; die Xhosadiens in Oos- en Wes-Kaapland; die Suid-Sothodiens in die Vrystaat en aan die Witwatersrand; die Noord-Sothodiens in Pretoria, Noord- en Noordoos-Transvaal; die Tswanadiens in Pretoria, Wes-Transvaal, Noordwes-Kaapland en die Vrystaat, en die Venda/Tsongadiens in die verre Noord-Transvaal.

Daarop ingestel om in te lig, op te voed en te vermaak, speel die programme terselfdertyd hulle rol om goeie verhoudings tussen blank en nie-blank in Suid-Afrika te verstewig. Die bydrae van die uitsendings tot die bewaring en uitbouing van die taal en kultuur van die onderskeie Bantoenasies van die Republiek is onberekenbaar groot.

Met betrekking tot programsamestelling, sluit elke diens die volgende in: nuusbulletins, nuuswaardige tydskrifprogramme, praatjies, godsdienstige uitsendings, hoorspele en vervolgverhale, kinder- en vroueprogramme, daaglikse skooluitsendings, programme vir oumense, vasvra- en besprekingsprogramme, hoorbeelde, 'n wye verskeidenheid musiekprogramme, landbou- en tuinbourubrieke, versoekprogramme, sportuitsendings en wedstrydprogramme.

Binne die raamwerk van die reeds vermelde doelstelling om inligting, opvoeding en vermaak te verskaf, beywer Radio Bantu hom in die besonder om selfwerksaamheid en diens- 
vaardigheid teenoor die eie gemeenskap by die Bantoe aan te moedig; om die Christelike boodskap aan hom oor te bring; om deur die uitsending van wat goed en mooi is in sy eie geskiedenis, tradisies en kulture by hom nasietrots te skep; om in eerste instansie ' $n$ Bantoeprogram uit te saai, maar om ook 'n kleur van die Westerse kultuur en vermaaklikheid aan te bied, en om te alle tye 'n middel te wees om die regte gesindheid tussen blank en Bantoe te bevorder.

Die volgende strofe uit een van die prysliedere wat Radio Bantu gereeld ontvang, vat die reaksie van duisende luisteraars op die programme beeldend saam:

„Wees gegroet, julle wat ons vermaak en opvoed!

Julle blitsvinnige boodskappers!

Julle wat geluk versprei ..."

\section{Afsluiting:}

'n Eerste gevolgtrekking uit 'n studie oor radio-ontwikkeling in en in verband met Afrika is dat die radio tans verreweg die belangrikste massa-kommunikasiemiddel op hierdie vasteland is.

Gedagtig daaraan dat groeps-luistergewoontes in sekere gebiede voorkom en die aantal luisteraars per stel in elk geval betreklik ruim in Afrika bereken kan word, sou dit nie ondenkbaar wees dat die bykans elfmiljoen radio-ontvangstelle in Afrika op die oomblik reeds vir 'n luistergehoor van tagtigtot honderdmiljoen kon sorg nie. Die skouspelagtige toename in ontvangstelle op die vasteland sedert die koms van die transistorradio, dui daarop dat nog veel meer van Afrika se 258-miljoen inwoners binne afsienbare tyd toegang tot die radio sal hê.

Gesien in die lig van die toenemende beskikbaarheid van luisteraars, kan die buitengewone bedrywigheid van sowel Afrikastasies as buitelandse omroepe om hulle Afrika-uitsendings so spoedig moontlik uit te brei en hoorbaar te maak, goed begryp word. Oor die belangrikheid om Afrika te bereik het daar by hulle nog nooit enige twyfel bestaan nie en die lug-stormloop om Afrika is gevolglik feller as ooit tevore.

Daar is daarop gewys dat 'n duidelike neiging tot 'n nuwe benadering van Afrika in hulle radioprogramme algaande in die jongste jare by die buitelandse dienste van oorsese uit- 
saaistasies te bespeur is. Daar word tot op groot hoogte ook nou in Afrikatale deur hulle uitgesaai en verskeie van hulle programme het 'n ,Afrika-karakter".

Soos voorts aangedui, het 'n studie van programinhoud aan die lig gebring dat daar wel in bepaalde uitsendings eerlik daarna gestreef word om in te lig, voor te lig, op te voed en te vermaak. In die besonder sorteer ook skooluitsendings van Afrikalande onder hierdie programme. Terselfdertyd is tot die gevolgtrekking gekom dat die radio in en na Afrika veral deur kommunistiese lande en sekere Afrikastate op gewetelose en gevaarlike wyse as belangrike instrument aangegryp word in die ideologiese propaganda-oorlog om die „siel" van Afrika. Hulle misbruik van 'n medium wat daarvoor bestem is om goedgesindheid en onderlinge begrip tussen volkere te bevorder, ken dikwels geen perke nie.

Daar is ook in die loop van die ontleding bevind dat in baie gevalle deur luisteraars in Afrika voorkeur aan die eie plaaslike stasie gegee word, veral wanneer plaaslike aangeleenthede en die plaaslike tale genoegsaam in ag geneem word. Terselfdertyd was daar duidelike aanduidings dat tog na die uitsendings van oorsese omroepe en ander Afrikastasies geluister word.

Indien daar egter uit die voorafgaande studie een allesoorheersende indruk verkry is, dan is dit dat die SAUK, ter wille van veel wat vir ons dierbaar is, 'n ontsaglike taak te vervul het in die lugruim bokant Afrika.

Die roepsein van Radio RSA wat telkens sy uitsendings vir die buitewêreld sal identifiseer, is 'n paar helder note uit die lied van die bokmakierie. Daar bestaan die volste vertroue dat hierdie note suiwer en welluidend sal opklink uit die kakofonie wat deurentyd die etergolwe vul.

Steve de Villiers

Johannesburg.

27 April 1966.

BELANGRIKSTE GERAADPLEEGDE BRONNE:

1. „Rundfunk und Fernsehen in Afrika" deur Harald Voss (Deutsche Afrika-Gesellschaft E.V. Bonn).

2. Kaarte en Statistieke oor Afrika: Kulturele en Opvoedkundige Aspekte (Afrika-instituut).

3. „World Radio TV Handbook" (World Radio-Television Handbook Co. 
Ltd., Sundvej 6, Hellerup, Denmark).

4. BBC Handbook 1965 (British Broadcasting Corporation, Broadcasting House, London W.1.).

5. Jaarverslae van die SAUK.

6. Sound and Vision Broadcasting, Volume 6, No. 3 (The Marconi Com-

pany Limited, Chelmsford, Essex, England).

7. Verskeie Suid-Afrikaanse en oorsese dagblaaie en tydskrifte, 1960-'66. 